\title{
SEARCHING FOR MEANINGFUL AFTERMATHS: DONOR FAMILY EXPERIENCES AND EXPRESSIONS \\ IN NEW YORK AND DENMARK
}

Anja Marie Bornø Jensen

\begin{abstract}
Focusing on the experiences of Danish and North American donor families, this article investigates the attempts to reinterpret brain death, the idea of organ donors 'living on', and the perception of the organ donor as a 'hero' or 'good citizen'. The study shows that the donor family experiences and recollections are deeply affected by the organizational context for families; including social interactions with staff, and the values and ideologies connected to organ donation in the specific cultural and national context.
\end{abstract}

\section{INTRODUCTION}

This article will discuss how North American (US) and Danish donor families interpret and articulate their experiences of consenting to organ donation. The discussion is based on anthropological field studies in New York and in Denmark and argues that during the search for closure, donor families transform their experiences of organ donation into meaningful aftermaths through interactions with the professional staff working with them. ${ }^{1}$

The research is based on two anthropological studies. The first involved four months of ethnographic fieldwork in 2005 in the Donor Family Aftercare Department of the New York Organ Donor Network (NYODN), one of the largest organ procurement organizations in the US. The second study is based on data from $\mathrm{PhD}$ research on organ donation in Denmark from 2008-2011, focusing on the Danish families of organ donors and the staff interacting with them in neuro intensive care units. ${ }^{2}$ For ethical reasons, my interviews with donor families in both New York and Denmark took place in the months and years after the donation. ${ }^{3}$ 
Anthropological literature on organ transplantation has dealt with a variety of topics. These include; organ trade (Scheper-Hughes 1996; 2004), the lack of organs and the commodification of the body (Joralemon 1995; Sharp 2000), the notion of gift exchange (Fox \& Swazey 1992; Healy 2006; Siminoff \& Chillag 1999; Sque \& Payne 1994), the experiences of organ recipients (Sharp 1995; Gutkind 1988), the social meanings of the body in modern medical technology (Hogle 1999, Ohniku-Tierney 1994; Sharp 2007), and the emotional and cultural problems of the brain death criterion (Alnæs 2001; Ben David 2005; Lock 2002a, 2002b, Youngner et al. 1996). Relatively few qualitative studies have been conducted regarding the experiences of donor families during and after the clinical encounter (Alnæs 2001; Haddow 2005; Jacoby et al. 2005, Sharp 2001, 2006).

I discuss the experiences of donor families by narrowing in on three specific areas: attempts to transform and translate a peculiar death such as brain death, the comforting or disturbing perceptions of the dead donors 'living on' in the bodies of transplant recipients, and the understanding of an organ donor as being either a hero or a good citizen. It is not my intention to evaluate best practices, rather the empirical examples I have chosen from my research in the US and Denmark shed light on the complexity of the donor family experiences.

I argue that families make different attempts to interpret and understand their experiences of organ donation in ways that are as meaningful and as sense making for them as possible. Some succeed in this, others do not, and most find organ donation both disturbing and meaningful. Anthropologist Edward Bruner explored the relationship between reality (life as lived), experience (life as experienced) and expressions (life as told). Bruner argued that experience structures expressions but expressions also structures experience. According to his thinking, it is in the performance of an expression that culture is reexperienced, re-told and re-constructed, and that meaning is created (Bruner $1986: 6,11)$. Not all donor families manage to turn the tragedy of losing a family member into something meaningful through telling stories. But this article shows that most families do attempt to transform their experiences in various ways, and that that it is performed very differently in the socio-cultural contexts of the US and Denmark.

Between Denmark and the US there are tremendous differences in the clinical, organizational and cultural contexts for performing, understanding and interpreting organ donation. Following Bruner, I suggest that this is the part of 
the reason why donor family experiences are expressed in extremely different ways across these two countries.

VISIBLE DEATH AND PEACEFUL CLOSURE

Organ donor patients in the intensive care unit (ICU) exhibit an astounding paradox: they are simultaneously dead and alive. The heart is beating, the body is breathing, the hand is warm to hold and to use the words of donor families: they 'look as if they are sleeping' (Jensen 2011). As studies from various countries describe, the brain death criterion challenges our understandings of the boundaries between life and death (Alnæs 2001; Ben-David 2005; Lock 2002a; Sharp 2006; Youngner et al. 1996). To establish brain death, two similar tests of the brain stem reflexes have to be done (with at least a one hour interval in between) by two doctors, one of them being a neuro specialist. Brain death cannot be diagnosed until 'all clinical evidence of consciousness and brain stem function is absent' (Pearson 1997: 69). Anthropologist Margaret Lock has argued that brain death is a state of 'betwixt and between', an 'invention of death' which is constructed to solve the shortage of organs (2002b). I often heard this argument among Danish hospital staff, a majority of whom believe firmly in brain death, but also understand why families have their difficulties. Engaging in organ donation raises fundamental questions regarding the body, life and death. Questions which frequently emerge include: Is it right to consider removing the heart from a person who is breathing? Can you allow the body of your loved one to be cut open by surgeons to help strangers? And is organ donation in accordance with traditions and ideals about dying peacefully? (Jensen 2011).

Both Danish and American donor families contemplate such existential questions and many consider the procedures of removing organs rather uncomfortable. Therefore, families need some kind of reassurance and closure, and this often occurs through undergoing a process of reinterpreting their experiences. I argue that in Denmark this is attempted by normalizing the death at the hospital, in the US this occurs by rhetorically transforming the death in the social forum of the Aftercare Department.

My research in Denmark shows that many families found the circumstances surrounding brain death frustrating. Due to the medical organ management and the technological surroundings of the intensive care units, families in my research stated it was difficult to find the privacy and peace needed to say goodbye, and to be present at the bedside of the donor even if the hospital staff was very considerate. I often observed families walking in and out of the 
wards; many were whispering and acting carefully so as not to disturb other patients or nurses. Even if nurses repeatedly allowed them to do what they found best, some families were clearly uncomfortable in the social surroundings of intensive care units.

During my fieldwork, I met Annika, a Danish woman in her late forties. She lost her husband Carl, the father of their four children, in a traffic accident. Annika was pleased and proud about Carl becoming an organ donor. She was a doctor herself and believed firmly in the brain death criterion. But the process at the intensive care unit made her aware of the many very difficult aspects of the processes of organ donation, such as saying goodbye while Carl's body was still breathing. She vividly described watching Carl being taken away from the intensive care unit to have his organs removed as 'the trip down death row'. Choosing to call it 'death row' indicates that emotionally for Annika, Carl was not dead yet when leaving the intensive care unit, and her feeling that Carl was about to suffer before he died. Annika explained that she was very appreciative that she and her children were offered the chance to say goodbye to Carl after the organs were removed. In Annika's own words this gave the family comfort and closure and reassurance that death had occurred. In this setting they felt they were allowed to cry and it initiated their grieving process in a good way. Annika explained:

You cannot say goodbye to somebody who is brain dead as long as he has colours and is warm and does not look any different. Mentally, that is impossible. It is so important to see him when he is what you understand as 'real dead' meaning cold and stiff and with pale colours. If the situation should arise again, and that was not an option, I am not sure I would say yes.

(Annika - Danish donor wife)

In Denmark, families are offered to have the donor brought back to the intensive care unit after the organs have been removed on the operating table. This process enables the family to say goodbye without the patient being connected to the respirator and they get a chance to see their family member 'real dead' or 'dead dead', to quote many Danish families and nurses. During this ceremonial event, the nurse lights a candle, opens a window and the family has the option to have a hospital chaplain present to say a prayer or sing a hymn. These rituals are a way of turning death into something that according to Danish traditions is familiar and comforting, namely saying goodbye to the dead when they are cold and pale and stiff. The Danish anthropologist Britt Boesen has conducted fieldwork at Danish hospitals and nursing homes and studied how dead bodies 
are handled until they are placed in the coffin. She argues that the corpse is both a subject-a human, and an object-a strange 'foreign body'. Boesen writes that 'the double status of the corpse is organized and controlled so we can give death a place in life' (Boesen in Hviid Jacobsen 2008:123). Boesen identifies 'the aesthetic guidelines' in the work of professionals dealing with the deceased, such as the folding of hands and the closing of eyes and mouth, to help 'make death appear like a time of rest' (Boesen in Hviid Jacobsen 2008:125).

The actions of the nurses around the body of the organ donor coming from the operation table can therefore be understood as a strategic way of using the well known aesthetics of a peaceful death to disguise that this body has not been treated as dead bodies normally are. By letting the family see the donor after the surgery, the death obtains some kind of visual and emotional closure. For many families this closure has been hard to sense as long as the brain dead body was still given medicine at the neuro intensive care unit.

My fieldwork surprisingly showed that these aesthetic practices are also performed to comfort the nurses. Many nurses find it very difficult not to perform the well known death rituals when sending a brain dead patient to the operating table. Kirsten, a Danish intensive care nurse was happy that most patients were brought back to their department after the operation, as she said, 'after the vultures had taken what they want'. Although Kirsten was in favour of the idea of organ donation and had been part of several organ donation cases, it still interfered with how she preferred to handle a dead body as a professional nurse and as a person.

The Danish hospital staff therefore stages such performances of peaceful death to support families and themselves. As we see in the case of Annika, the last visual goodbye and the possibility to see the presence of the death peace is a very important for the way organ donation is experienced and perceived, which affects her general attitude to organ donation. By visually experiencing a well known death, in contrast with the unfamiliarity of the brain death criterion, families and staff in close interaction achieve a quiet and more socioculturally meaningful moment of goodbye after the hectic technological process of establishing brain death and managing the organs.

To complicate matters, not all donor families are comforted by this last goodbye. Some refuse to return to see the donor after the surgery and a few of my family informants were surprised and uncomfortable to see how pale the donor was. One Danish family was upset to be told by very frustrated intensive care nurses that their daughter was not stitched as properly together as organ 
donors normally are. This was a one-of-a-kind incident in my research since Danish operation nurses are extremely careful about respecting the body of the organ donor. However, it shows that the post surgery appearance of the body of the organ donor is a very emotionally sensitive matter for nurses as well as for families.

After Danish donor families have said their goodbyes, they leave the hospital and literally speaking, they disappear from the health care system. Contacting the families afterwards is not regionally or nationally organized but depends on the individual nurse and of the economic resources and time priorities of the particular unit. This is one of the most significant differences between the US and Denmark, and as we shall see, it has an impact on the donor family experience.

ORGANIZATIONAL AFTERCARE AND NEW VOCABULARIES

In the New York Organ Donor Network, all donor families were automatically enrolled in the Aftercare Department. Aftercare for donor families was a twoyear program consisting of bereavement cards, letters of thanks from the President of the NYODN, phone calls to the families, information about the organs, invitation to social events and acknowledgement ceremonies. The Aftercare programme also offered donor families the option to communicate anonymously with the organ recipients and to meet other donor families. Aftercare staff was available by phone if families wanted to call with any questions or concerns. My fieldwork showed that these conversations could concern doubts about whether 'brain death' really meant dead, the wish to know what went on in the operating room when removing the organs, or getting to know how the organ recipients were doing. Sometimes the conversations expressed a mere need to talk to somebody who was on the phone to listen and show understanding (Jensen 2007, 2010).

According to the Manager of the organization, one of the major ways to support the family was to 'provide them with terminology' through which to speak about their experiences (Jensen 2010). This terminology included statements such as 'organs are gifts', that organs were 'recovered' not 'harvested', and that their loved one is 'spiritually living on', and will 'never be forgotten'. The specific use of words acted to provide families with value-laden superlatives to classify their actions. As a fundamental part of the program, the staff continuously emphasized the impact of the donation, and honourably acknowledged the families' decision, knowing that this was comforting and reassuring. The intention was double. The process of creating of good stories would counsel and comfort traumatized grieving families. But the good stories about organ 
donation could also convince the public to sign the donor registry and limit biased experiences that would act as bad Public Relations (PR). In NYODN staff repeated that 'donor families are our best advocates', and 'if donor families have a good experience with organ donation, they will tell 50 people, if they have a bad one they will tell 500' (Jensen 2007,2010 ). Therefore there was a great organizational strategic interest in making sure that positive family stories were promoted. The negative ones were either transformed into something else or silenced. The organization made families take courses in how to speak publicly about their personal experiences with organ donation and they did not allow newly bereaved, angry or frustrated families to do public speaking (Jensen 2007:41).

Many American donor families remembered that the statements of the organization had clearly affected their personal experience and dominated the public versions of their stories. But in more personal and confidential interview settings, both sides of the coin were revealed, and the co-existing narratives of organ donation as both a triumph and a nightmare became evident to me. One story from an American donor family was shared by Jack whose teenage son Mark who shot himself in their house. Jack showed how the organizational slogan of 'turning tragedy into triumph' was incorporated in the sanitised and public expression of his experience. However, later in the interview, Jack revealed that the visual idea of organ donation was tearing him apart.

[Organ donation] has helped us to come to the realization that this horrible incident was unavoidable, that he was involved in. And we took that tragedy and we turned it into a triumph by making other people's lives better because of Mark.

(...) I had been drinking a lot, and I had been abusing legally prescriptive sleep medication, but I was not using it properly. And the reason I was using both, was because of the dreams I was having and the visions of Mark on the operating table that I could not get rid of. (Jack - American donor father)

The organizational orchestration of stories can therefore also be looked upon as attempts to stage certain perceptions of the death and of organ donation. Mark should be remembered as a young man who saved lives through his death, not as a tragic suicide or a maltreated body on an operating table (Jensen 2010). Telling stories which focussed on celebrating and glorifying organ donation meant that some families were not allowed to do public speaking, and therefore alternative narratives surrounding organ donation are not able to emerge. Such as for instance the story of Grace. Her mother had chosen 'only' 
to donate tissue and not solid organs, and because of this Grace explained that she was afraid her mother's body 'was stored in a freezer somewhere'.

Language is used in a rhetorical attempt to make death meaningful for families and for a public audience. Anthropologist Michael Jackson argues that when people make words stand for the world, it is possible to manipulate one's experience of the world (Jackson 2002:18). Following this idea, organizational aftercare for donor families 'manipulates' families' devastating experiences and re-interprets them into something sense-making for the families and for the ongoing and future PR efforts regarding organ donation. In this organizational setting, it became very evident that the purpose was not only to take care of donor families, it was also to create, shape and stage certain stories of absence, and link personal grieving with an organizational purpose (Jensen 2010).

In Denmark, the option of Aftercare and vocabularies which might be seen as either 'comforting' or 'manipulating' is not present. Rather, it is left to the hospital staff to accompany families in their attempts to make the rather peculiar death of an organ donor make sense by visually emphasizing the occurrence of a well known death after the organ removal. In the US, the follow up efforts of Aftercare rhetorically translate the frustrations of death and organ donation into something heroic, honourable and sense making. Although there are regional, cultural and organizational differences between the US and Denmark, the purpose is the same: to create an alternative version of death that is more reassuring, comforting and peaceful than the emotionally disturbing elements that can dominate the donor family experience of brain death and organ donation.

\section{THE COMFORT IN ONGOING LIVES}

I know he is not dead. He is alive in other people that are out there today. He is just not with me, but he is out there in other people... And that for some reason has given me great solace, knowing that other people are benefiting from my son's death instead of just putting his body in the grave and saying goodbye. And that is the end of it. That is not the case.

(Kenny - American donor father)

The American organizations not only shape the structures and values for speaking about the organ donors; they also provide a stage on which the performance of presenting the deceased can be acted out without any questions. On this stage, the memories and the continued lives of the deceased are cel- 
ebrated. During public speaking, Kenny, the American donor father from the quote above made sure to constantly mention that the body parts of his son were helping ' 84 people in 24 different states'. This very tangible and quantitative fact helped him preserve the presence of his son. Knowing that the body of his son was out there helping others and imagining the organs (and thereby the son) still being 'alive', gave him comfort and purpose and thereby served as a meaningful aftermath.

According to sociologist Kieran Healy, donor families can form a meaningful sense of the continuing survival of the donor (Healy 2006:34). They look at death as a continuation of life - it is just in another form, and it is not with them. This is generated by organizational understandings of organ donation that makes these new patterns of interpretation possible (Jensen 2007:43). But it is also generated by the opportunities given to organ donor families to do public speaking which fit very well in the PR strategies of the organization. In this social performance, donors are still present because of the articulation of organ donation and the value-laden biographies. These stories and the strategic purpose they fulfill might not make sense outside the organizational context. But, the organizational context acts as a certain kind of social forum in which the dead live on through the performance of stories about the revitalization of their spirit through the donation of organs (Jensen 2010). An American donor mother told me that she remembered somebody saying, 'a person is only dead when you stop talking about them'. Therefore she was very active in talking about her dead daughter. She actively used the many forums of the organization to tell and retell her story in order to reinterpret her daughter's death.

Anthropologist Edward Schieffelin discusses something similar in his classic work Performance and the Cultural Construction of Reality (1985) where he examines the performance of non-discursive spirit séances among the Kaluli people of Papua New Guinea. According to him, performance does not construct a symbolic reality. Rather performance helps construct a setting in which the participants can experience symbolic meanings as part of the process of what they are already doing (Shieffelin 1985). If so, then the performance of organ donation is deeply dependent on the options for constructing a setting in which the performance makes sense (Jensen 2011). In the right setting, new realities and believable versions of the death can be created.

Within the American organizational context, the performance of stories about dead organ donors living on is not only performative. It is experienced as a reality for families, marking a strong belief that the dead are present in spirit. American families told me that they felt their deceased family members were 
suddenly present when they were talking about organ donation.

Even if American donor family stories might be different in form and in purpose from the Danish ones, the point I wish to make is that stories need a social forum in which the performance can take place and in which this particular reality can be constructed. According to Jackson, it is not enough to focus on the 'product of narrative activity', what is important is the social process of storytelling (Jackson 2002: 18).

A comparison with the Danish situation is difficult since there is no organizational forum where meaningful stories can be created and performed. Most Danish donor families do not imagine their dead family members living on in others, but some are very interested in knowing the outcome of the organs. However, a few Danish families in my study regarded the donation of body organs as disturbing the death peace in some sense as we shall see in the next section.

\section{FEELING DISCOMFORT IN CIRCULATING PARTS}

Eva is a Danish woman in her late thirties who lost her mother due to a brain aneurism. My interview with Eva was dominated by her expression of doubt about whether she did the right thing in accepting the father's decision to donate her mother's organs. Eva was very unsatisfied with the way she was handled by Danish hospital staff. She felt that the doctors regarded her mother as too old to go through surgery to try to save her brain, and she was also startled by the fact her mother was then not too old to become an organ donor. Eva felt she was not able to cry out her grief and to properly say goodbye to her mother because of her mother's location in a four bed ward on an intensive care unit. In my research, Eva stood out as one of the only family members who regretted saying 'yes' to organ donation (Jensen 2011). I asked Eva if she knew what had happened to her mother's organs. My question evoked a strong reaction from Eva who with tears in her eyes sharply pointed out that it was questions like these that objectified her mother. Eva put it like this:

No God dammed. And I would never meet anyone walking around with her. I would want to rip their heart out of them. (...) I would rather pretend I do not know. My mother is dead and I would like her to remain that way. Half of her should not be running around everywhere. I just want her to be dead and I have to understand that. (...) When you ask about this, you objectify my mother's organs and you objectify her as if she was a store of spare parts.

(Eva - Danish donor daughter) 
The body parts of Eva's mother, relocated in the bodies of different people, was a symbol of the strife and conflict Eva felt in the situation in the ICU, representing the extra grief she had about not being able to give the mother a peaceful death (Jensen 2009). In this way, Eva's story can be distinguished from the comfort in ongoing lives so vividly expressed by many American families. Her experiences provide a sharp contrast to the positive association connected with 'the gift', dominating the ideology of organ donation both in Denmark and elsewhere. Her story is also a strong contrast to the meaningful narratives constructed in the donor family-aftercare interaction in New York.

From my research in Denmark I experienced how hard it can be for families to articulate the experiences of organ donation without undergoing a sociocultural process of finding new language through which to imagine donation. Thereby it is difficult to construct some kind of ending to the death and to the story of losing a family member. During my fieldwork I met with Henning who told me that his wife Karin had lost her life in a traffic accident where she was hit by their neighbors' loader tractor. Karin was in her mid forties and the mother of four children. The interview clearly showed that Henning found the process of organ donation extremely hard to articulate.

I have no language for what has happened. I don't know how to explain my kids what has happened. What can I answer when they ask me where Mom is? And Jeppe, my six year old, asked me, 'If we can find out where the heart is, will Mom be there?' That was his question. And I answered 'No that is not how it is. Mom is dead. And her heart is working in another person.' That is our terms as donor families. We have to make it up, because we cannot meet the people who have received, so to speak, our organs. But there is no language. How can my kids and I cope with death? Where is Mom? (...) Perhaps I should have gone to the hospital and asked 'Isn't there some kind of club I can join. Can't you do something? You owe me an explanation. Somebody has to do something. (Henning - Danish donor husband)

Henning expresses aggravation over the lack of language to explain to his children what happened. His account also points to the lack of closure often connected to organ donation, making these stories hard to finish in a proper way, since the final destiny of the body parts remains unknown due to the needs of the organ recipients not having to face the origins of their new parts. Henning calls this the 'terms of donor families', and it clarifies another characteristic of the social consequences of organ donation: when people do not know where 
the body parts of their family member have ended up, it is hard to construct a meaningful aftermath. For Henning and his family, the organ donor death cannot ever reach a final closure, and they will never felt it has ended. The search and the questions will continue. But it is also important to notice, that Henning's frustration is not only caused by the search for the organs but also by the search for 'some kind of club' to join. He needs an explanation for what actually happens to his wife's body parts and he needs 'somebody to do something. With this, Henning expresses a need other Danish donor families also were longing for, namely some kind of social support available for families afterwards.

From this we learn that if the donor family stories about the exchange of organs are not socially created and socially shared in a context of mutual understanding, telling such stories can involve repeating frustrations (and can be re-traumatizing to families) rather than stories becoming a supportive way of both remembering and constructing new realities. Specific stories about organ donation can therefore only be a rewarding element in the processes of creating a meaningful aftermath, if the performance of the stories is taking place in a certain social setting. Such a setting is not currently present in Denmark, but it does exist in the US through their aftercare efforts and the social forums for donor families and due to the organizational benefit in constructing organ donation positively through the narratives of donor families. I am not claiming that Danish donor families will never be able to construct meaningful narratives of organ donation or that American families always find meaning in organ donation. However, many Danish families are often left alone with bad stories and bad memories and with many unanswered questions. They are also denied the option of sharing experiences or receiving acknowledgement, since such options are not prioritized in the organizational work on organ donation in Denmark (Jensen 2011). The national and socio-cultural context in which organ donation happen clearly plays a significant role for donor families since their experiences are articulated, performed and received very differently in different contexts.

\section{BRAVE HEROES}

Anthropologist Linda Hogle has done research on organ transplantation in Germany and linked the history of the nation to perceptions of the body. Hogle argues that in order for a nation or a health care system to accept apparently inhuman procedures of handling dead bodies, a 'cultural mechanism' to translate the concepts of brain death and organ donation must be initiated (Hogle 1999, Jensen 2011). I suggest that reframing and restorying organ dona- 
tion as something 'heroic' is a way of translating this practice into something unambiguously 'good'. Writing about organ donation in an Israeli context, anthropologist Orit Brawer Ben-David claims that a 'heroic death' involves giving one's life for one's country. When soldiers die in battle the personal body becomes symbolically a part of the social body of the nation (Ben-David 2005:108,127). Other types of deaths such as suicides or traffic accidents do not have the same social significance or symbolism and are therefore not categorized as heroic deaths. However, consenting to organ donation can transform such ordinary ways of dying into 'heroic deaths' which are thus deserving of national attention and recognition (Ben-David 2005).

In the NYODN the idea of an organ donor being a hero was constructed or indulged with a not only a therapeutic purpose for the donor family but also as a way to use a familiar metaphor to associate organ donation with culturally acceptable and admirable values. Many American donor family informants adopted this idea about the donor as 'a hero saving other people's lives' because it reassured them that there was a purpose or a meaning to the death, thus providing families with a socially accepted model for re-interpreting a tragic loss (Jensen 2010).

During my fieldwork in 2005, I went to an information day about organ donation at Mount Sinai Hospital in New York. I listened to the story of Joseph, the father of two small children who lost his wife due to a bleeding in the brain. Joseph was still very upset about the loss of his wife, and talked about the difficulties in getting through the daily life with two small children. But during the interview, it turned out that some elements of his story were carefully orchestrated and thought through. Sitting across from me, Joseph quickly returned to one of the important elements of the story, the hero narrative:

Then I went home to explain to my kids what had happened. And my daughter was only five and did not understand life and death, so when I told her, she cried, she begged and pleaded for me to take her to heaven just for one minute to say goodbye to Mom. But my son was 13 and he understood what was happening. And when I told him that his Mom had died, he cried and cried and we hugged for a long time. In search for something to tell him, I started explaining organ donation to him and that she was going to be able to save somebody's life. Through his tears he looked up at me and said 'That makes Mom a hero, doesn't it'. And I said, 'I guess it does'. And from that day on, we think of her as a hero, as someone, who maybe ran through a burning building and pulled some people out 
before being overcome by the smoke and flames herself. And it is that, what has really gotten us through this whole grieving process. (Joseph - American donor husband)

As I have argued elsewhere (Jensen 2007; 2010) for donor families in New York the heroism of saving others often had a reference to the terror attacks on World Trade Centre on September 11th 2001 (9-11). Families often incorporated their version of 9-11 into their stories about losing a family member and consenting to organ donation. However, the heroism in the stories of the families was not exclusively confined to the urban context of the terrorist attacks; it also acquired a national character in the personal and public remembrance of organ donors. Anthropologist Lesley Sharp points to how donor memorials often are similar to war memorials showing that the hero theme is very evident in how organ donors are officially memorialized in America (2006). Personal stories were placed in a nationalistic frame of understanding:

And I can think of nothing else other than standing in front of a bullet and getting shot for the President of the US or something that a secret service agent will do that is more heroic than being an organ donor and having made that decision to let the medical team do whatever they need to do with their body to help other people to live. (Jack - American donor father)

THE DUTY OF GOOD CITIZENS

In Denmark, organ donation is not connected to heroism and has no public narrative. There is no public acknowledgement of organ donors and their families. It is kept within the family and is rarely a topic for public discussion. Danish families connected organ donation to the rather undefined idea of helping others. In Denmark the notion of heroism is not a socially negotiated frame of understanding that can help translate the unfamiliar figure of organ donation into familiar cultural narratives (Jensen 2011). That does not mean however that the Danes do not place organ donation in a cultural or national frame in order to construct a meaningful aftermath. Denmark is a Welfare state with free health care. Many Danes have a very strong social relationship to their country and see the country as something that will help and support them if needed. This luxury entails certain obligations, and for many Danes, organ donation is one of them. The story of Jens illuminates this.

I interviewed 68 year old Jens in his penthouse apartment in a large Danish city. While sitting in his couch sipping coffee I was told about the loss of his 
ex-wife Kate. Jens and Kate had been clear about organ donation for many years, so when she died the decision was not hard. Jens found the hospital staff extremely professional and was positively surprised to learn that they could use her kidneys even if she was 69 years old. Unlike many other families, Jens was not so emotionally affected by sharing his story. Instead he focused pragmatically on the rationale for his family's decision, and the more general social obligations of donating organs in the Danish context:

I don't see it as a gift; I see it as an attitude. As a natural thing living in the society we do. I mean. We do expect that somebody will come and pick us up if we fall and take care of us. And if somebody is hurt and needs a kidney, then I find it reasonable if somebody that is checking out can deliver a useable kidney. (...) I consider it the same as helping an old lady that had fallen in the street. I would stop my car and help her on her feet. My fundamental attitude is that as a Danish citizen I can use the facilities in this country. And then it is natural for me that I also have an obligation, when I am not part of the party anymore that they can use whatever parts and bits they like. And I think that should be a part of the Danish citizenship or whatever. (...) If you draw on the system you have to contribute to the system. If I need a kidney or another spare part, I might be lucky that society provided me with the spare part I needed. And it goes both ways. So I have difficulties understanding opposing arguments. (Jens - Danish donor husband)

Jens's narrative opens a window to investigate how organ donation is closely related to the attitudes, values and history of the surrounding society and the obligation as citizens. Jens sees organ donation as an unquestionable part of being a responsible Danish citizen. Mentioning his own expectations about being 'picked up' one day himself, Jens' decision to donate is his way of contributing to the health care system he considers himself a part of. Jens opens our eyes to notions of social s solidarity between Danes and their country. Organ donation is not something extraordinary like taking a bullet for the American president. It is something you do as a 'natural' way of expressing your relationship to your country. In anthropologist Anne Hambro Alnæs's (2001) study in Norway she gives the example of a young married couple choosing to donate organs from the wife's sister as a way of paying back and saying thank you to the country for having helped them with artificial insemination during the conception of their first child. This adds new perspective to the influential idea of the 'tyranny of the gift' suggested by sociologists Fox and Swazey (1992) who argue that the gift of organ donation is so extraordinary that it can never be 
fully reciprocated. Donor family statements such as those cited above suggest that giving organs is not like giving a gift, it is a reciprocal action confirming a person's position in an already existing exchange relationship with their country and the Welfare State.

By comparing the act of donation to the everyday necessity of helping an old lady across the street, Jens constructs organ donation as indisputably good. Jens draws an analogy between being an organ donor and what it means to be a good citizen in Danish society. Through arguing that you have to contribute to the system if you expect to draw upon the system, Jens place the act of organ donation within a larger system of exchange between citizen and country and as an expression of solidarity (Jensen 2011). To many Danish families such as Jens, giving organs should not result in special treatment or recognition. Danish families are modest about their actions and do not want a thank you or too much 'fuss'. Therefore, if the Danish health care system ever considers providing organized aftercare for Danish donor families, the structure, form and contents need to be 'translated' to reflect Danish socio-cultural values, habits and norms.

Expressing the donation of organs as an expected act of solidarity constitutes a meaningful aftermath for Jens. Contrary to the American donor families needing a stage to perform their meaningful recollections of organ donation, the actual and largely private action of donating organs at the hospital constitutes the stage upon which Jens is able to perform his social relationship and articulate his solidarity towards his country. Therefore for some Danish families, an organizationally structured reframing and reinterpretation of experiences is not necessary, as the social meaning is self-evident. Simply by framing your own actions when donating as an act which is a fundamental part of 'being Danish', the donation of organs in itself can shape a meaningful aftermath and give families peace of mind. The neuro intensive care units in Danish hospitals can be understood as the stage where donor families expresses their loyalty and belonging to Denmark by consenting to organ donation. Following Schieffelin, a reality is created where organ donation is the 'right thing to do'.

\section{CONCLUSION}

This article has shown the many ways in which organ donation is articulated and performed in Denmark and in the US. It is done by allowing families a peaceful goodbye as we saw from the Danish material, and through rhetorically transforming devastating experiences to hero narratives within a social forum, as represented by American Aftercare efforts. Donor families also con- 
template the ongoing lives of donors because of the circulating organs. To many American families the immortality of donors is constantly performed through public speaking, and the construction of stories without end. Danish donor families imagine the improved lives of recipients and in rare cases, find the idea of circulating parts disturbing. Finally, I have shown that organ donation initiates imagination about doing something good for your country, whether it is staged as an act of heroism as in the US, or as an act of solidarity expressing and confirming an already existing exchange relationship to your country, as in Denmark.

Overall, these examples have shown the more or less conscious attempts donor families make to turn the experiences of brain death and donation into something meaningful, to reach some kind of peace of mind, or to create alternative biographies or futures for the dead donors. Sometimes this is achieved afterwards and in other incidences the act of donating itself is how families construct meaning. As impossible as it may sound to attempt to obtain meaning from a tragic death, these recollections of Danish and American donor families have the potential not only to teach us about discourses and constructions within the world of organ donation, but also about fundamental socio-cultural values regarding life, death and national belonging in Denmark and the US.

\section{NOTES}

1 I thank two anonymous reviewers for their insightful comments and Dr. Rhonda Shaw for her generous suggestions for amendments to this article.

2 I thank The Danish Research Council for Culture and Communication for funding my PhD. project and The Danish Heart Foundation for financial support for the fieldwork in Denmark. Above all, I thank the donor families and medical professionals participating in my studies.

3 In the New York Organ Donor Network, my formal position was 'research internship. This position allowed me to meet and interact with donor families according to the ethical guidelines of the organization. Thus, no special ethical permission was necessary. In Denmark, only studies involving medical research in human tissue need formal ethical approval. I negotiated the access and ethical guidelines with each intensive care unit individually. Both studies are performed under the current ethical standards of the Department of Anthropology, University of Copenhagen. All informants have been promised anonymity. Hence, the names in this article are pseudonyms. 


\section{REFERENCES}

Alnæs, A.H. 2001 Minding Matter. Organ Donation and Medical Modernity's difficult Decisions Department and Museum of Anthropology, The Faculty of Social Sciences. University of Oslo.

Ben-David, O.B. 2005 Organ Donation and Transplantation: Body Organs as an Exchangeable Socio-Cultural Resource. Westport, Connecticut, London: Praeger.

Boesen, B. 2008 'Det døde menneske - både subjekt og objekt' in Jacobsen M.H. \& Haakonsen, M. (eds) Memento Mori - Døden i tvorfagligt lys. University of Southern Denmark Studies in History and Social Sciences, 368: p123-138.

Bruner E.M. 1986 'Experience and its expressions', in V. Turner \& E. Bruner (eds) The Anthropology of Experience, Chicago: University of Illinois Press:3-30.

Fox, R. and Swazey, J.P. 1992 Spare Parts: Organ Replacement in American Society. Oxford: Oxford University Press.

Gutkind, L. 1988 Many Sleepless Nights: The World of Organ Transplantation. Pittsburgh: University of Pittsburgh Press.

Haddow, G. 2005 'The Phenomenology of death, embodiment and organ transplantation', Sociology of Health and Illness, 27 (1): 92-113.

Healy, K. 2006 Last Best Gifts. Altruism and the Market for Human Organs. Chicago: The University of Chicago Press.

Hogle, L. 1999 Recovering the Nation's Body: Cultural Memory, Medicine and the Politics of Redemption. Rutgers University Press, New Brunswick, New Jersey and London.

Jackson, M. 2002 The Politics of Storytelling: Violence, transgression and Intersubjectivity Museum Tusculanum Press, University of Copenhagen.

Jacoby L., Breitkopf and Pease 2005 'A Qualitative Examination of the needs of Families faced with the option of organ donation', $D C C N, 24(4): 183-189$.

Jensen, A.M. 2007 Those Who Give and Grieve - an Anthropological Study of American Donor Families. Master Thesis No.430. Department of Anthro- 
pology, University of Copenhagen.

Jensen, A.M.B. 2009 'Mistede liv og nye chancer. Kropsdelenes komplekse sociale betydninger i organdonationsfeltet', Tidsskrift for Sygdom og Samfund nr. 11 2009:3150.

Jensen, A.M.B. 2010 'A sense of absence. The staging of heroic deaths and ongoing lives among American organ donor families', in Bille, M., Sørensen. T.F. \& F. Hastrup (eds) An Anthropology of Absence; Materialisations of Transcendence and Loss, Springer Press: 63-82.

Jensen, A.M.B. 2011 (forthcoming) Orchestrating an Exceptional Death - Donor Family Experiences and Organ Donation in Denmark. PhD Series no. 69, Department of Anthropology, University of Copenhagen.

Joralemon, D. 1995 'Organ wars: the battle for body parts', Medical Anthropology Quarterly, 9:335-356.

Lock, M. 2002a Twice Dead: Organ Transplantation and the Reinvention of Death, Berkeley: University of California Press.

Lock, M. 2002b 'Inventing a new death and making it believable', Anthropology \& Medicine, 9(2): 97-115.

Oniku-Tierney, E. 1994 'Brain Death and Organ Transplantation: Cultural Bases of Medical Technology', Current Anthropology, 35 (3):233-254.

Pearson, I.Y. 1997 'Brain Death', in Chapman J.R, Deierhoi M., Wight C. (eds) Organ and Tissue Donation for Transplantation, Oxford University Press, New York.

Scheper-Hughes, N. 1996 'Theft of Life: Organ Stealing Rumours', Anthropology Today, 12(3):3-11.

Scheper-Hughes, N. 2004 'Parts Unknown', Ethnography, 5(1):29-73.

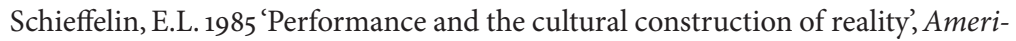
can Ethnologist, 12(4):707-724.

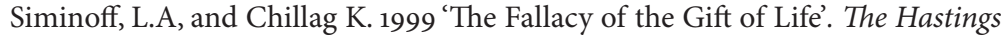
Center Report, 29(6):34-41. 



pological insights into the Restructuring of the Self', Medical Anthropology Quarterly, 9(3):357-389.

Sharp, L.A. 2000 'The commodification of the body and its parts', Annual Review of Anthropology, (29):287-328.

Sharp, L.A. 2001 'Commodified kin: Death, mourning and competing claims on the bodies of organ donors in the United States', American Anthropologist,103(1):112-133.

Sharp, L.A. 2006 Strange Harvest: Organ Transplants, Denatured Bodies and the Transformed Self. Berkeley: University of California Press.

Sharp, L.A. 2007 Bodies, Commodities \& Biotechnologies, Death, Mourning \& Scientific Desire in the Realm of Human Organ Transfer, Columbia University Press, New York.

Sque, M. and Payne S. 1994 'Gift exchange theory: A critique in relation to organ transplantation', Journal of Advanced Nursing, (19): 45-51.

Youngner, S.J., Fox R.C. and O'Connell, L.J. (eds) 1996 Organ Transplantation: Meanings and Realities. Madison: The University of Wisconsin Press. 